Journal Club

Editor's Note: These short reviews of recent JNeurosci articles, written exclusively by students or postdoctoral fellows, summarize the important findings of the paper and provide additional insight and commentary. If the authors of the highlighted article have written a response to the Journal Club, the response can be found by viewing the Journal Club at www.jneurosci.org. For more information on the format, review process, and purpose of Journal Club articles, please see http://jneurosci.org/content/ preparing-manuscript\#journalclub.

\title{
Adult Neural Stem Cell Multipotency and Differentiation Are Directed by the Methyl-CpG-Binding Protein MBD1
}

\author{
Elad Lax and Daniel M. Sapozhnikov \\ Department of Pharmacology and Therapeutics, McGill University, Montreal, Quebec H3G 1Y6, Canada \\ Review of Jobe et al.
}

The generation of new neurons in the subventricular zone of the dentate gyrus during adulthood is indispensable to hippocampaldependent learning and memory formation (Gonçalves et al., 2016). A decrease in neurogenesis is associated with increased anxiety, depression, and other neurodevelopmental disorders (Jacobs et al., 2000; Taliaz et al., 2010). The source of new neurons is a population of neural stem cells (NSCs) in the dentate gyrus that can selfrenew and give rise to new neurons and astrocytes. Evidence shows that epigenetic mechanisms tightly regulate the "stemness" of NSCs and the complex genetic pathways that determine their commitment to discrete lineages.

One of the most studied epigenetic modifications is DNA methylation. The addition of a methyl group to the fifth carbon of cytosines within promoters prevents the binding of transcription factors and results in a reduction of gene expression. Because this activity is essential for proper development throughout the body, it is reasonable to ex-

Received Feb. 13, 2017; revised March 23, 2017; accepted March 25, 2017.

E.L. was supported by the Richard and Edith Strauss Postdoctoral Fellowship in Medicine, McGill University. D.M.S. was supported by the Discovery Grants Program of the Natural Sciences and Engineering Research Council of Canada and the James Frosst Fellowship from the Department of Pharmacology and Therapeutics, McGill University.

The authors declare no competing financial interests.

Correspondence should be addressed to Dr. Elad Lax, McGill University, 3655 Promenade Sir William 0sler, Room 1309, Montreal, Quebec H3G 1Y6, Canada.E-mail: eladlax@mail.mcgill.ca.

DOI:10.1523/JNEUROSCI.0411-17.2017

Copyright $\odot 2017$ the authors $\quad 0270-6474 / 17 / 374228-03 \$ 15.00 / 0$ pect perturbation of this important regulatory mark to alter NSC behavior. The detrimental effects on neurogenesis observed after deletion of the DNA methyltransferase DNMT3A and the demethylation-promoting protein Gadd45b (Ma et al., 2009; Wu et al., 2010) support this hypothesis.

DNA methylation does not regulate gene expression exclusively through the steric interference of transcription factor binding, however. Instead, methylated DNA can serve as a signal for the recruitment of methylated DNA binding proteins, such as Mecp2 and methyl-CpG binding domain (MBD) 1-6. This family of proteins is characterized by a specific MBD that preferentially interacts with methylated DNA. The binding of MBD proteins to methylated DNA is commonly associated with gene repression (Du et al., 2015).

Several MBD proteins are important for NSC differentiation and adult neurogenesis. Transgenic rodent models of Rett syndrome, in which MeCP2 is mutated or duplicated, show reduced neurogenesis (Tsujimura et al., 2009; Chen et al., 2017), and phosphorylation of serine 421 of MeCP2 regulates differentiation and proliferation of NSCs (H. Li et al., 2014). Other recent examples include the role of MBD3 in neural cell differentiation in the cortex (Knock et al., 2015) and of MBD5 in balancing NSC differentiation and proliferation (Gigek et al., 2015).

Previous studies revealed that MBD1 is also necessary for proper neurogenesis. Lack of $\mathrm{MBD} 1$ resulted in impaired hippocampal activity and autistic-like behaviors in mice (Zhao et al., 2003; Allan et al., 2008). Since then, it has become clear that, at least in part, MBD1 binds and stabilizes methylated DNA at the promoters of Fgf 2 and $m i R-184$ in cultured NSCs, represses the expression of these factors, and thereby enables neuronal differentiation (X. Li et al., 2008; Liu et al., 2010). Yet, the role of MBD1 in the intact adult dentate gyrus remained unexplored.

In a recent study in The Journal of Neuroscience, Jobe et al. (2017) further probed the mechanism by which MBD1 orchestrates the complex self-renewal and differentiation processes underlying neurogenesis. In a comprehensive set of immunohistochemical experiments, the researchers examined the expression pattern of MBD1 in the dentate gyrus, where NSCs either differentiate to become astroglia or undergo a serial maturation through progenitor stages (Types 1, 2a/b, and 3) before ultimately developing into mature neurons. Jobe et al. (2017) found that MBD1 was expressed in NSCs and adult neurons but not in immature neurons or astrocytes. Accordingly, they found that MBD1 knock-out caused an accumulation of intermediate Type $2 \mathrm{a} / \mathrm{b}$ progenitor cells, with an apparent differentiation block that prevented the cells from progressing to become Type 3 cells and mature neurons. These observations explain previous reports of overall reduced neurogenesis and the resulting abnormal behaviors that accompany MBD1 knock-out (Zhao et al., 2003). 
Using wild-type and MBD1 knock-out mice that harbor a GFP reporter downstream of the NSC marker nestin, Jobe et al. (2017) used FACS to isolate putative NSCs from the dentate gyrus. RNA sequencing of these nestin-positive cells revealed that 270 genes were differentially regulated in knockout and wild-type mice (124 were more highly expressed in knock-out and 146 were expressed at lower levels in knock-out). Notably, MBD1-deficient NSCs were characterized by increased expression of astrocyte markers and reduced expression of neuronal genes. Indeed, in vitro experiments confirmed impaired neuronal commitment in MBD1 knock-out NSCs. Together, the results of this study provide compelling evidence of the role of MBD1 in the maintenance of NSCs and proper neuronal differentiation and commitment.

Despite a lack of high-quality MBD1 antibody, Jobe et al. (2017) were able to show the expression pattern of MBD1 in NSCs and the lineages to which they contribute by using a previously established MBD1 knock-out mouse model (Zhao et al., 2003). In these mice, exons $2-10$ of the MBD1 gene were replaced by a sequence encoding $\beta$-galactosidase, allowing the use of an antibody against this enzyme to identify cells that normally express MBD1. However, it is well established that the double-strand break and homologous recombination involved in the introduction of this foreign DNA result in radical changes in DNA methylation, histone modification, and expression of adjacent genes (Russo et al., 2016). Because the first exon and promoter were included in the targeting vector as part of the homology arm required for recombination, it is exceedingly likely that the epigenetic marks in these regions were altered by the knock-out. Moreover, this targeting vector was not methylated, and its introduction into the endogenous DNA could potentially introduce an unmethylated promoter into every cell in the animal. The expression patterns of MBD1 in this mutant therefore may not necessarily recapitulate the endogenous distribution of MBD1. Although this knockout strategy is widely used and accepted, it is necessary to consider the artifacts it may introduce into immunohistochemical experiments. Future development of a high-quality antibody against MBD1 could provide strong supportive evidence for the current findings.

In the current study and a previous study (Jørgensen et al., 2004), MBD1 was suggested to act as a repressor that binds DNA and silences gene expression. Therefore, the authors focused on the ability of MBD1 to repress lineage differentiation genes and presented the aberrant activation of these genes upon MBD1 knock-out as a primary mechanism for inappropriate and incomplete neuronal differentiation. However, the RNA-sequencing data from wild-type and knock-out MBD1 dentate gyrus NSCs suggest a more complex view. Although expression of lineage differentiation genes was increased in knock-out mice, expression of more than half of the transcripts measured actually decreased. This phenomenon may seem counterintuitive if MBD1 exerts its effects solely by means of a repressive activity, as its relief by knock-out would be expected to invoke an overall increase in gene expression. There are several possible explanations for the decrease in gene expression, however, as discussed below.

Although classically considered transcriptional repressors, recent findings suggest that some MBD proteins can induce gene expression. For example, in the hypothalamus, $\mathrm{MeCP} 2$ was found to activate the vast majority of genes that it affected. Mechanistically, an interaction between MeCP2 and the transcriptional activator CREB1 was deemed responsible for the promoting expression (Chahrour et al., 2008). More recently, MeCP2 was demonstrated to recruit CREB1 to maintain Foxp3 expression to preserve the suppressive functions of regulatory $\mathrm{T}$ cells during inflammation (C. Li et al., 2014). Furthermore, MBD2 was shown to promote expression of the glucocorticoid receptor in the hippocampus via interaction with Egr1 (Zif268) (Weaver et al., 2014). Interestingly, MBD2 exerts bidirectional influence on transcription by binding with either HDAC2, as part of a repressive complex, or with TACC3 and the histone acetyltransferase $\mathrm{pCAF}$, as part of a reactivating complex (Angrisano et al., 2006). MBD3 behaves in an analogous manner and can bind both DNA methyltransferases and MBD2 to increase or decrease DNA methylation, respectively (Cui and Irudayaraj, 2015).

All four isoforms of MBD1 contain the transcriptional repression domain, a critical region responsible for the silencing activity of MBD1. However, given the complex effects of other MBD proteins on DNA methylation and gene expression, it is possible that MBD1 can promote gene expression, either independently or through its binding partners, by a mechanism that has yet to be discovered. It is thus important to note that the transcriptional repression domain of MBD1 is intrinsically disordered (Hameed et al., 2014), and it is conceivable that it may therefore promiscuously interact with unidentified transcriptional activators.

An alternative hypothesis is that MBD1 exclusively represses target genes, but genes downregulated by MBD1 knock-out are hier- archically regulated. For example, MBD1 might inhibit the expression of transcriptional repressors that, upon MBD1 knock-out, are now unhampered and able to reduce expression of downstream genes. This indirect model of MBD1-mediated upregulation reconciles the prevailing theory that classifies $\mathrm{MBD} 1$ as a repressor with the downregulation observed in RNA-sequencing experiments by Jobe et al. (2017).

These hypotheses can be resolved by well-constructed studies that involve a combination of chromatin immunoprecipitation sequencing and gene expression analysis in NSCs. If this approach reveals that MBD1 does not directly bind to genes downregulated in MBD1 knock-out mice, this would support the aforementioned hierarchical model. However, if the downregulated genes exhibit MBD1 binding under physiological conditions, it will be necessary to entertain the possibility that $\mathrm{MBD} 1$ is not a strict transcriptional repressor and to devise experiments to identify its binding partners. Together, such a comprehensive approach might provide a detailed understanding of the intricate effects of MBD1 binding on gene expression and its influential role in adult neurogenesis. Nonetheless, by elucidating the mechanisms by which MBD1 influences NSC maintenance and differentiation, Jobe et al. (2017) provide insights into the complex epigenetic pathways that regulate the dynamic cellular changes underlying memory formation in the hippocampus.

\section{References}

Allan AM, Liang X, Luo Y, Pak C, Li X, Szulwach KE, Chen D, Jin P, Zhao X (2008) The loss of methyl-CpG binding protein 1 leads to autism-like behavioral deficits. Hum $\mathrm{Mol}$ Genet 17:2047-2057. CrossRef Medline

Angrisano T, Lembo F, Pero R, Natale F, Fusco A, Avvedimento VE, Bruni CB, Chiariotti L (2006) TACC3 mediates the association of MBD2 with histone acetyltransferases and relieves transcriptional repression of methylated promoters. Nucleic Acids Res 34:364-372. CrossRef Medline

Chahrour M, Jung SY, Shaw C, Zhou X, Wong ST, Qin J, Zoghbi HY (2008) MeCP2, a key contributor to neurological disease, activates and represses transcription. Science 320:12241229. CrossRef Medline

Chen Z, Li X, Zhou J, Yuan B, Yu B, Tong D, Cheng C, Shao Y, Xia S, Zhang R, Lyu J, Yu X, Dong C, Zhou WH, Qiu Z (2017) Accumulated quiescent neural stem cells in adult hippocampus of the mouse model for the MECP2 duplication syndrome. Sci Rep 7:41701. CrossRef Medline

Cui Y, Irudayaraj J (2015) Dissecting the behavior and function of MBD3 in DNA methylation homeostasis by single-molecule spectroscopy and microscopy. Nucleic Acids Res 43:3046-3055. CrossRef Medline

Du Q, Luu PL, Stirzaker C, Clark SJ (2015) 
Methyl-CpG-binding domain proteins: readers of the epigenome. Epigenomics 7:1051-1073. CrossRef Medline

Gigek CO, Chen ES, Ota VK, Maussion G, Peng H, Vaillancourt K, Diallo AB, Lopez JP, Crapper L, Vasuta C, Chen GG, Ernst C (2015) A molecular model for neurodevelopmental disorders. Transl Psychiatry 5:e565. CrossRef Medline

Gonçalves JT, Schafer ST, Gage FH (2016) Adult Neurogenesis in the Hippocampus: From Stem Cells to Behavior. Cell 167:897-914. CrossRef Medline

Hameed UF, Lim J, Zhang Q, Wasik MA, Yang D, Swaminathan K (2014) Transcriptional repressor domain of MBD1 is intrinsically disordered and interacts with its binding partners in a selective manner. Sci Rep 4:4896. CrossRef Medline

Jacobs BL, van Praag H, Gage FH (2000) Adult brain neurogenesis and psychiatry: a novel theory of depression. Mol Psychiatry 5:262-269. CrossRef Medline

Jobe EM, Gao Y, Eisinger BE, Mladucky JK, Giuliani CC, Kelnhofer LE, Zhao X (2017) Methyl-CpG-binding protein MBD1 regulates neuronal lineage commitment through maintaining adult neural stem cell identity. J Neurosci 37:523-536. CrossRef Medline

Jørgensen HF, Ben-Porath I, Bird AP (2004) Mbd1 is recruited to both methylated and nonmethylated $\mathrm{CpGs}$ via distinct DNA binding domains. Mol Cell Biol 24:3387-3395. CrossRef Medline

Knock E, Pereira J, Lombard PD, Dimond A, Leaford D, Livesey FJ, Hendrich B (2015) The methyl binding domain 3/nucleosome re- modelling and deacetylase complex regulates neural cell fate determination and terminal differentiation in the cerebral cortex. Neural Dev 10:13. CrossRef Medline

Li C, Jiang S, Liu SQ, Lykken E, Zhao LT, Sevilla J, Zhu B, Li QJ (2014) MeCP2 enforces Foxp3 expression to promote regulatory $\mathrm{T}$ cells' resilience to inflammation. Proc Natl Acad Sci U S A 111:E2807-E2816. CrossRef Medline

Li H, Zhong X, Chau KF, Santistevan NJ, Guo W, Kong G, Li X, Kadakia M, Masliah J, Chi J, Jin P, Zhang J, Zhao X, Chang Q (2014) Cell cycle-linked MeCP2 phosphorylation modulates adult neurogenesis involving the Notch signalling pathway. Nat Commun 5:5601. CrossRef Medline

Li X, Barkho BZ, Luo Y, Smrt RD, Santistevan NJ, Liu C, Kuwabara T, Gage FH, Zhao X (2008) Epigenetic regulation of the stem cell mitogen Fgf- 2 by Mbd1 in adult neural stem/progenitor cells. J Biol Chem 283:27644-27652. CrossRef Medline

Liu C, Teng ZQ, Santistevan NJ, Szulwach KE, Guo W, Jin P, Zhao X (2010) Epigenetic regulation of miR-184 by MBD1 governs neural stem cell proliferation and differentiation. Cell Stem Cell 6:433-444. CrossRef Medline

Ma DK, Jang MH, Guo JU, Kitabatake Y, Chang ML, Pow-Anpongkul N, Flavell RA, Lu B, Ming GL, Song H (2009) Neuronal activityinduced Gadd45b promotes epigenetic DNA demethylation and adult neurogenesis. Science 323:1074-1077. CrossRef Medline

Russo G, Landi R, Pezone A, Morano A, Zuchegna C, Romano A, Muller MT, Gottesman ME, Porcellini A, Avvedimento EV (2016) DNA damage and repair modify DNA methylation and chromatin domain of the targeted locus: mechanism of allele methylation polymorphism. Sci Rep 6:33222. CrossRef Medline

Taliaz D, Stall N, Dar DE, Zangen A (2010) Knockdown of brain-derived neurotrophic factor in specific brain sites precipitates behaviors associated with depression and reduces neurogenesis. Mol Psychiatry 15:80-92. CrossRef Medline

Tsujimura K, Abematsu M, Kohyama J, Namihira M, Nakashima K (2009) Neuronal differentiation of neural precursor cells is promoted by the methyl-CpG-binding protein $\mathrm{MeCP} 2$. Exp Neurol 219:104-111. CrossRef Medline

Weaver IC, Hellstrom IC, Brown SE, Andrews SD, Dymov S, Diorio J, Zhang TY, Szyf M, Meaney MJ (2014) The methylated-DNA binding protein MBD2 enhances NGFI-A (egr-1)mediated transcriptional activation of the glucocorticoid receptor. Philos Trans R Soc Lond B Biol Sci 369:1652. CrossRef Medline

Wu H, Coskun V, Tao J, Xie W, Ge W, Yoshikawa K, Li E, Zhang Y, Sun YE (2010) Dnmt3adependent nonpromoter DNA methylation facilitates transcription of neurogenic genes. Science 329:444-448. CrossRef Medline

Zhao X, Ueba T, Christie BR, Barkho B, McConnell MJ, Nakashima K, Lein ES, Eadie BD, Willhoite AR, Muotri AR, Summers RG, Chun J, Lee KF, Gage FH (2003) Mice lacking methyl-CpG binding protein 1 have deficits in adult neurogenesis and hippocampal function. Proc Natl Acad Sci U S A 100:6777-6782. CrossRef Medline 